\title{
ANALYSIS OF PROBLEMATIC ISSUES IN BUILDING AN EFFECTIVE BANK COMPLIANCE SYSTEM
}

\author{
๑) 2018 ZHUKOV V. V., KOTSIUBA 0. V.
}

УДК 338.242.2; 336.025; 336.71.078.3

JEL Classification: G21; K33

Zhukov V. V., Kotsiuba O. V.

Analysis of Problematic Issues in Building an Effective Bank Compliance System

In the context of the globalization of the banking market and increased risks, there arises a need for a reliable system to ensure financial security and stability of a bank as well as compliance with all domestic and international standards, norms, and rules. These tasks can be solved by a compliance system. In the article, a morphological analysis of this concept is carried out, and the author's own vision of the interpretation of this concept is presented. The proposed bank compliance system is based on the main financial methods (organization, analysis, planning, and control) and the principles of compliance developed by the Basel Committee. The organization of compliance can be provided at 2 levels: at the level of a banking institution and at the level of the banking system as a whole. A bank can create an independent compliance department or include the function of compliance control in the responsibilities of the legal department. At the level of the national banking system, compliance control is exercised by the National Bank of Ukraine. Compliance risks that are subject to analysis and planning within the framework of a compliance system include legal, reputational, operational, informational, and money laundering risk. Compliance control is aimed at ensuring conformity of actions of a bank's management with domestic regulations.

Keywords: risk management, compliance, risk management in banking, financial stability of a bank.

DOl: https://doi.org/10.32983/2222-0712-2018-4-226-232

Fig.: 2. Tbl.: 1. Bibl.: 13.

Zhukov Vladlen V. - Candidate of Sciences (Economics), Associate Professor, Associate Professor of the Department of Banking, Simon Kuznets Kharkiv National University of Economics (9a Nauky Ave., Kharkiv, 61166, Ukraine)

E-mail:Zhukv.vadim@gmail.com

ORCID: 0000-0003-4367-5596

Researcher ID: D-7072-2018

Kotsiuba Olena V. - Postgraduate Student, Department of Banking, Simon Kuznets Kharkiv National University of Economics (9a Nauky Ave., Kharkiv, 61166, Ukraine)

E-mail: kotsiubaelena@gmail.com

ORCID: 0000-0003-1365-1788

УДК 338.242.2; 336.025; 336.71.078.3

JEL Classification: G21; K33

Жуков В. В., Кочюба О. В. Аналіз проблемних аспектів побудови ефективної системи комплаєнсу в банку

В умовах глобалізації банківського ринку та підвищених ризиків виникає необхідність забезпечення надійної системи фінансової безпеки і стабільності банку, а також дотримання відповідності усіх внутрішніх положень регулювання діяльності банку до вітчизняних і мжннародних стандартів, норм і правил. Ці задачі може вирішувати система комплаєнс. У роботі було проведено морфологічний аналіз цього поняття та надано власне бачення трактування цього поняття. Запропонована система комплаєнсу у банку базується на основних фінансових методах (організація, аналіз, планування та контроль) і принципах комплаєнсу згідно з рекомендаціями Базельського комітету. Організачію комплаєнсу може бути забезпечено на 2 рівнях: на рівні банківської установи та на рівні банківської системи в цілому. Банк може створити окремий самостійний структурний підрозділ комплаєнсу або включити функцію комплаєнсу до повнованень юридичного департаменту. На рівні банківської системи країни функиія комплаєнсу забезпечується Начіональним банком України. До комплаєнс-ризиків, які $\epsilon$ об'єктом аналізу та планування в рамках системи комплаєнс, можна віднести юридичний, репутаційний, операційний, інформаційний та ризик відмивання коштів. Комплаєнс-контроль спрямований на забезпечення відповідності дій банківського менеджменту вітчизняним нормам.
UDC 338.242.2; 336.025; 336.71.078.3 JEL Classification: G21; K33

Жуков В. В., Коцюба Е. В. Анализ проблемных аспектов построения эффективной системы комплаенс в банке

В условиях глобализации банковского рынка и повышенных рисков возникает необходимость обеспечения надежной системы финансовой безопасности и стабильности банка, а также соблюдения соответствия всех внутренних положений регулирования деятельности банка отечественным и международным стандартам, нормам и правилам. Эти задачи может решать система комплаенс. В работе был проведен морфологический анализ данного понятия, и представлено собственное видение трактовки этого понятия. Предложенная система комплаенс в банке базируется на основных финансовых методах (организация, анализ, планирование и контроль) и принципах комплаенса согласно рекомендациям Базельского комитета. Организация комплаенса может быть обеспечена на 2 уровнях: на уровне банковского учреждения и на уровне банковской системы в целом. Банк может создать отдельное самостоятельное структурное подразделение комплаенс или включить функцию комплаенс в полномочия юридического департамента. На уровне банковской системы страны функция комплаенс обеспечивается Национальным банком Украины. К комплаенс-рискам, которые являются объектом анализа и планирования в рамках системы комплаенс, можно отнести юридический, репутационный, операционный, информационный и риск отмывания денег. Комплаенс-контроль направлен на обеспечение со- 
Ключові слова: ризик-менеджмент, комплаєнс, управління банківськими ризиками, фінансова стабільність банку.

Pис.: 2. Табл.: 1. Бібл.: 13.

Жуков Владлен Валерійович - кандидат економічних наук, доцент, доцент кафедри банківської справи, Харківський національний економічний університет ім. С. Кузнеия (просп. Науки, 9а, Харків, 61166, Україна)

E-mail: Zhukv.vadim@gmail.com

ORCID: 0000-0003-4367-5596

Researcher ID: D-7072-2018

Кочюба Олена Володимирівна - аспірант, кафедра банківської справи, Харківський національний економічний університет ім. С. Кузнеия (просп. Науки, 9а, Харків, 61166, Україна)

E-mail: kotsiubaelena@gmail.com

ORCID: 0000-0003-1365-1788 ответствия действий банковского менеджмента отечественным нормам.

Ключевые слова: риск-менеджмент, комплаенс, управление банковскими рисками, финансовая стабильность банка.

Рис.: 2. Табл.: 1. Библ.: 13.

Жуков Владлен Валерьевич - кандидат экономических наук, доцент, доцент кафедры банковского дела, Харьковский национальный экономический университет им. С. Кузнеца (просп. Науки, 9а, Харьков, 61166, Украина)

E-mail: Zhukv.vadim@gmail.com

ORCID: 0000-0003-4367-5596

Researcher ID: D-7072-2018

Кочюба Елена Владимировна - аспирант, кафедра банковского дела, Харьковский национальный экономический университет им. С. Кузнеца (просп. Науки, 9а, Харьков, 61166, Украина)

E-mail: kotsiubaelena@gmail.com

ORCID: 0000-0003-1365-1788
The banking market is a structure that is developing quite dynamically. Given the active European integration processes, an important aspect is to bring all banking laws and regulations in line with EU legislation. This process is called compliance and currently is the focus of research of a number of scientists.

Works of I. Astrakhantseva, O. Bereslavska, N. Vnukova, Ya. Zhariy, L. Kalinichenko, L. Kliusko, O. Sarahman [1, 2; 3, $5,6 ; 7,11]$ present a detailed analysis of the mechanism for building a compliance system in banking institutions, as well as general principles of compliance risk management within the risk management system of a bank. However, the issue of introducing and using a compliance system in the context of integration of the domestic banking system into international markets has not been extensively studied and requires further consideration.

The aim of the article is to analyze the main structural elements of a bank compliance system and determine reserves to ensure its effective functioning.

Compliance is an element of corporate governance. The Organization for Economic Co-operation and Development (OECD) in its document "Principles of Corporate Governance" defines corporate governance as a structured system that involves both analysis of and control over the achievement of the desired results. At the same time, the processes can be considered as functions of compliance [13].

The Basel Committee on Banking Supervision has developed a report entitled Compliance and the Compliance Function in Banks, which defines the principles of institutional organization of compliance (Fig. 1) [12].

The presented principles of building an effective compliance system are generalized and fundamental, which allows using them in activities of any bank. Each bank, taking into account its specificity of activities and priorities defined by the state, society, co-founders, and management, focusing on the market for banking services and competitors, develops and implements relevant rules that define features of its compliance policy. -This can occur in arranging the structure of departments, building the system of interaction with customers, etc. In more detail this aspect will be considered further in the article.

The implementation of a compliance system in the practice of domestic banking institutions is only at the initial stage, while foreign experience demonstrates that such systems are used by banks very actively, providing positive financial results.

Compliance as a process is present in practical banking in the form of a compliance system (Fig. 2). The purpose of this system is to exercise effective control over the occurrence of compliance risks and their effective management in a banking institution.

A bank as a structural element of the economic environment is influenced by certain external factors, such as:

- political - changes in the nature and structure of legal acts, regulations, instructions on activities of banking institutions, etc.;

- economic - changes in the economic climate in the country and the level of purchasing power of the population, emergence of competitive products from other market actors, etc.;

- social - increase or decrease in public confidence in a banking institution, outflow of human capital from the banking sector to other areas of activity due to unsatisfactory working conditions, etc.;

- financial - changes in the basic standards of banking regulation (volume of regulatory capital, size of discoun - the use of banking institutions for money laundering and terrorist financing, etc.

All the above mentioned and other factors have a positive or negative effect on the activities of a financial institution, creating the threat of compliance risks.

According to A. Podderogin, any financial system should use 4 general methods in their work: organization, accounting (analysis), planning, and control.

Organization as one of the financial methods of the compliance system includes informational support and organizational support both at the level of a banking institution and at the level of the banking system as a whole. 
Know YourCustomer - Know Your Customer - before carrying out a financial transaction, the bank must identify and verify the identity of its client and its counterparty

Due Diligance - Due Diligence - procedure for a multifaceted study of a company, comprehensive analysis of its financial status and reputation in the market, formation of a fair view of the investee, including evaluation of investment risks and independent assessment of the investee

Code of Conduct - the code of rules to which financial market participants are recommended to adhere in order to protect the rights of investors and improve other aspects of corporate management

Code of Ethics - the document defining the priorities of an organization, which are ensured by observance of moral and ethical principles, standards of conduct, and conscientious performance of duty by employees
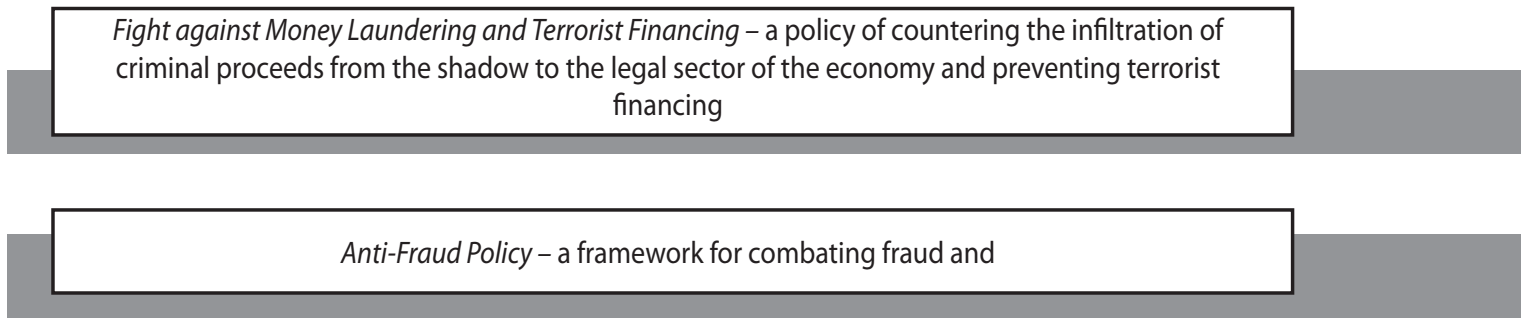

Whistleblowing policy - regulates the procedure and methods for the reporting of misconduct of bank employees

Gift policy - determines the rules defining actions of employees when taking presents from customers, partners, suppliers or giving them to partners, customers, etc.

Privacy policy - ensures non-disclosure of data about customers and their operations and involves the observance of standards for the processing and storage of personal data

Conflict of interest management policy - defines ethical standards of employee behavior in the event of a conflict of interest between an employee and the company. Bank interests should always be prioritized

Fig. 1. Principles of institutional organization of compliance, according to the Basel Committee [12]

Informational support includes internal, all-Ukrainian, and international banking regulations; guidelines, instructions regulating the procedure of risk management and establishing the rules and principles for constructing a risk management system. The list of normative legal acts used for the research purposes is given below.

Among the main international banking regulations are recommendations made by the Basle Committee (Basel I, Basel II, Basel III, Basel IV). The mentioned normative documents contain detailed provisions on the procedure for calculating regulatory capital as well as the procedure for managing the credit, market and operational types of risks.

Another group of documents which contain important provisions on combating money laundering are the recommendations of the International Financial Action Task Force on Money Laundering (FATF). More than 90 legal documents define general methods for managing the risk of money laundering; rules for implementing the system for combating this process; procedures for client identification and verification, in particular, in the context of a banking institution, etc.

Among the main state regulations that relate to the issue of financial stability of banks as subjects of primary financial monitoring, is the Law of Ukraine "On Preventing and Counteracting to Legalization (Laundering) of the Proceeds of Crime, Terrorist Financing, and Financing Proliferation of Weapons of Mass Destruction". This document defines banks as subjects of primary financial monitoring, provides a list of their rights and obligations, establishes a procedure for identifying and verifying a client as part of assessing the risk of money laundering with the use of the banking system. 


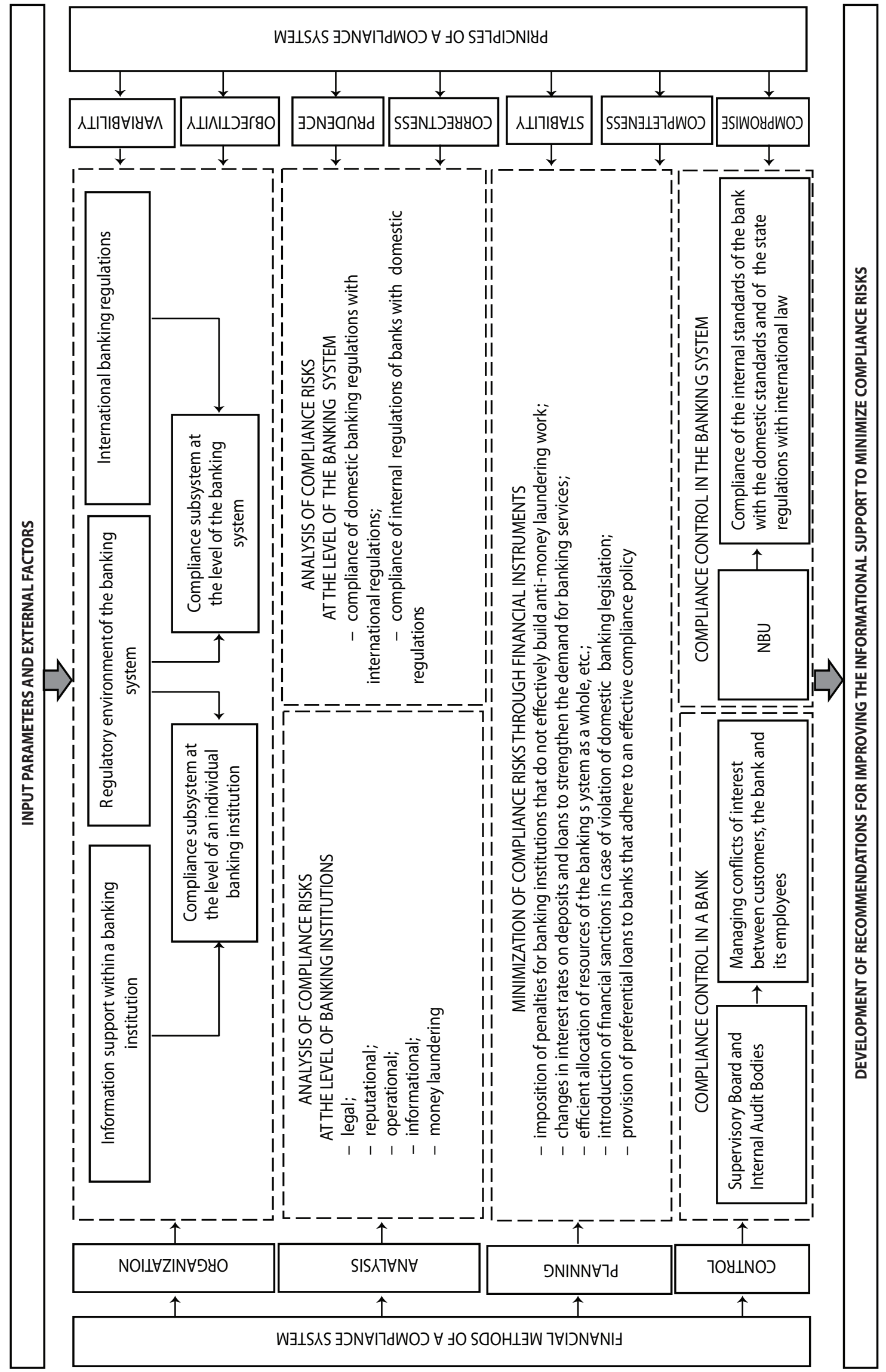


More detailed provisions in this area are established by the Resolutions of the Board of the National Bank of Ukraine "Regulation on Implementation of the Financial Monitoring by Banks".

The procedure for calculating regulatory capital and economic standards is stipulated by the Resolution of the NBU "On Approval of the Instruction on the Procedure for Regulating the Activities of Banks in Ukraine".

The legislation of Ukraine at the national level regulates only the issue of credit risk assessment, in accordance with the Resolution of the Board of the National Bank of Ukraine "On Approval of Regulations on Determination by Banks of Ukraine of the Extent of Credit Risk on Active Banking Activities". The Resolution provides detailed information on how to assess extent of credit risk, according to the methodology presented in Basel II, based on a rating approach. Assessment of other types of risks, such as operational and market risks, is not regulated at the state level.

The Resolution of the Board of the National Bank of Ukraine "About Approval of the Regulations on the Organization of Internal Control in Banks of Ukraine" provides general recommendations on monitoring compliance of internal activities of banks with the national legislation and international regulations.

Organizational support at the bank level as an element of such a financial method of the compliance system as organization represents those structural units that at the level of an individual bank ensure compliance risk management. In the document "Compliance and the compliance function in banks" issued by the Basel Committee on Banking Supervision the expression "compliance function" is used to describe staff carrying out compliance responsibilities [12]. The role and place of the compliance function in the activity of a separate bank depends on its size. Thus, in large banks, the compliance function should diversify its work with respect to each of the banking products. Banks operating in the international arena should also establish regional compliance offices. Small banks can create only one organizational structure to carry out compliance responsibilities, which will ensure information security and countering money laundering.

The bank can independently regulate the role and place of the compliance function depending on the degree of manifestation of a particular type of risk (for example, operational or informational, etc.). For example, if a bank's management believes that the informational risk is most threatening, compliance responsibilities can be carried out by the bank's security department. For compliance monitoring a bank can set up a separate department, but its activities should be in conformity with the general risk management system of the bank.

Specialists engaged in the compliance function should control the development of basic compliance principles to be adhered to at all levels of the banking management system. It is important to develop general provisions that regulate actions of all bank employees within the framework of compliance risk management. Moreover, the senior management of the bank with the help of the compliance function should:

- at least once a year identify and evaluate the compliance risks faced by the bank;

- at least once a year submit a report to the board of directors or the Compliance Risk Committee on the degree of effectiveness of the bank's compliance policy;

- report to the board of directors on any negative situations that may entail additional examinations by regulatory authorities, material and financial losses or loss of reputation.

The distribution of functional responsibilities among the structural units of a bank within the compliance system can occur under different scenarios. In some banks, e.g., the legal department may be responsible for monitoring internal normative legal acts in terms of compliance, for elaborating rules and standards for the preparation of personnel instructions. At the same time, the compliance department can be responsible for the conformance of the bank's compliance system to the established policies and international rules. In other banks, part of responsibilities of the compliance department may be transferred to the operational risk division or the risk department as a whole. In any case, it is necessary to ensure effective collaboration among the structural units.

Organizational support for compliance at the level of the banking system implies ensuring the conformity to and gradual implementation of the international standards, norms, and rules in the system of domestic legislation in the field of banking regulation. The main subject of compliance at the level of the banking system is the NBU.

Compliance risks are one of the elements of a compliance system and are objects of accounting and planning within the framework of financial methods of the compliance system. The implementation of compliance implies the mandatory responsibility of the compliance manager to the senior management and employees for the identification and management of compliance risks. However, within the domestic legal framework there is no clear regulation concerning the types of risks that are classified as compliance ones. Therefore, banks should independently identify banking risks as factors to be accounted by the compliance system as well as develop systems for managing them. However, it should be noted that the risks that are most often included in the number of compliance risks (namely, legal, informational, reputational, operational, and money laundering risk) always have a negative effect on banking activities. Therefore, the goal of managing them is not optimization but minimization of risks.

It should be noted that the presence of compliance risks is not always critical for a bank. Risks always exist in any sphere of banking activity and they are not always measurable. It is important to conduct a qualified risk analysis, develop effective recommendations for reducing and managing risks.

Based on the analysis of the specialized literature, it is concluded that domestic authors classify operational, reputational, legal, informational risks, and money laundering risks as compliance risks. Considering these types of risks is logical in view of the essence of compliance control, within which compliance risks are the object of attention. Thus, a compliance control system aims to:

- manage conflicts of interest between the bank and its employees and customers;

- protect information and counter the use of the bank for money laundering and terrorist financing.

In regulatory documents, compliance risk is defined as "the risk of legal sanctions, financial loss, or loss to reputation 
a bank may suffer as a result of its failure to comply with laws, market regulations, as well as the bank's standards and internal documents" [9]. Failure of the bank to comply with legislation or violation of the norms of financial ethics may be caused by human factors and result in the emergence of an operational risk [2, p. 314].

Since a compliance risk is a multidimensional phenomenon, it can be viewed as an aggregate manifestation of the main types of functional risks that form and increase the risk, strengthening the negative impact on financial security (Tbl. 1).

Thus, the synergistic effect of the occurrence of legal, reputational, operational, informational risk, and the risk of money laundering is the object of analysis and planning in the compliance system at the level of the banking system. It should be noted that these and other types of risks always exist in activities of a banking institution. In view of this, management should develop effective measures to minimize risks in compliance with international and domestic standards, norms, and instructions, as well as business ethics of banking.

In the specialized literature, the concepts «compliance» and «compliance control» can be equated. However, the concept «compliance control» is a structural element of the compliance system and is limited only to monitoring conformity to the requirements and rules of the NBU for banking institutions, as well as a set of measures and methods aimed at identifying problem situations and monitoring activities of banking institutions [7; 8].

Compliance control is carried out in three dimensions:

- information flow management;

- customer relationship management;
- management of mechanisms for countering the legalization of proceeds from criminal activity [10, p. 88].

Information flow management involves the establishment of uniform internal rules for the use of insider information when concluding transactions with customers and conducting banking operations. Management must control the distribution of insider information not only within the framework of the bank's relations with external counterparties but also within units and departments. Customer relationship management and management of mechanisms for countering the legalization of proceeds from criminal activity requires bilateral client-bank cooperation, which is regulated by the Law of Ukraine «On Preventing and Counteracting to Legalization (Laundering) of the Proceeds of Crime, Terrorist Financing, and Financing Proliferation of Weapons of Mass Destruction».

Conclusion. The bank compliance system is part of the general management of a banking institution. The main structural elements of compliance are informational and organizational support, the system of compliance risk management and compliance control. Continuous cooperation between the compliance department and security department will enable a dynamic monitoring of occurrence of the main bank functional risks and making weighted and effective decisions to minimize negative consequences of the risks.

An important role in ensuring an effective functioning of a bank is played by constant monitoring by the bank's management of changes in the domestic legal framework and timely adaptation of internal regulations, which can be considered as a direction for further research. On the other hand, it is necessary to apply the international practice of banking regulation in the domestic legal framework. It also implies the need to

Table 1

Characteristics of the aggregate manifestation of the main types of functional risks classified as compliance risks

\begin{tabular}{|c|c|c|}
\hline Risk & Causes of risk & Consequences of risk \\
\hline Legal & $\begin{array}{l}\text { - changes in the legal framework; } \\
\text { - court decisions against bankrupt banks; } \\
\text { - delays in considering laws important for the } \\
\text { banking sector, etc. }\end{array}$ & $\begin{array}{l}\text { - ineffective adaptation of the bank to changes in } \\
\text { the legal framework; } \\
\text { - decline in lending activity; } \\
\text { - impossibility of optimizing banking activities due } \\
\text { to inadequate legislation }\end{array}$ \\
\hline Reputational & $\begin{array}{l}\text { - failure of the bank and its staff to comply with } \\
\text { legislation, ethical standards, etc.; } \\
\text { - insufficient transparency of the bank's activities; } \\
\text { - failure of the bank to fulfill its obligations to } \\
\text { customers }\end{array}$ & $\begin{array}{l}\text { - decline in the customer appeal of bank products; } \\
\text { - decrease in customer loyalty to the bank; } \\
\text { banking sector as a whole }\end{array}$ \\
\hline Operational & $\begin{array}{l}\text { - imperfect corporate governance; } \\
\text { - outdated technologies; } \\
\text { - abuse of authority by employees of the bank }\end{array}$ & $\begin{array}{l}\text { - incurring losses; } \\
\text { - slow and inefficient work; } \\
\text { - decrease in customer loyalty to the bank and loss } \\
\text { of its reputation }\end{array}$ \\
\hline Informational & $\begin{array}{l}\text { - absence of information open or available to the } \\
\text { bank; } \\
\text { - deliberate provision of false information by } \\
\text { customers; } \\
\text { - problems that arise at the strengthening of } \\
\text { cooperation or mergers of several banks }\end{array}$ & $\begin{array}{l}\text { - loss of reputation by the bank; } \\
\text { - poor customer identification; } \\
\text { - errors and interruptions in the work of the bank }\end{array}$ \\
\hline Money laundering & $\begin{array}{l}\text { - ineffective system of customer identification; } \\
\text { - lack of the financial monitoring unit; } \\
\text { - indeterminate limits on active banking transactions }\end{array}$ & $\begin{array}{l}\text { sanctions on the part of subjects of the state } \\
\text { financial monitoring }\end{array}$ \\
\hline
\end{tabular}


implement the objectives of the compliance system not only at the level of a banking institution but at the level of the banking system as a whole as well.

\section{LITERATURE}

1. Астраханцева И. А., Дубов Д. А., Кутузова А. С. Комплаенс-контроль в коммерческом банке. URL: http://www. astrakhantseva.ru/pub/fin_2014_6.pdf

2. Береславська О. І. Перспективи імплементації рекомендацій Базельського комітету в практичну діяльність банків України. Наукові записки Херсонського начіонального університету. Серія «Економіка». 2013. Вип. 23. С. 262-266.

3. Внукова Н. М. Управління ризиками фінансових установ у сфері фінансового моніторингу. Наукові записки Національного університету «Острозька академія». Серія «Економіка». 2018. № 8 (36). С. 64-68.

4. Гончарова К. Г. Система комплаєнс як елемент економічної безпеки банку. Вісник Черкаського університету. Серія «Економічні науки». 2015. № 33 (366). С. 27-36.

5. Жарій Я., Куфаєва В. Комплаєнс-модель процесу забезпечення фінансової безпеки комерційного банку. Проблеми і перспективи економіки та управління. 2016. № 2 (6). С. 312 319.

6. Калініченко Л. Л. Теоретичні аспекти функціонування комплаєнсу у вітчизняних банках. Науковий вісник Херсонського державного університету. Серія «Економічні науки». 2014. Вип. 6. Ч. 4. С. 242-245.

7. Клюско Л. А. Фінансовий моніторинг та комплаєнсконтроль в банках. Финансы, учет, банки. 2014. № 1 (20). C. $153-160$.

8. Ковальчук О. Поняття системи комплаєнс-контроль та особливості управління ризиком комплаєнс у банках України. Молодь іринок. 2010. № 7. С. 153-157.

9. Коляда І. В. Поняття та сутність комплаєнс-контролю у вітчизняній економічній науці та суспільному дискурсі. Молодий вчений. 2016. № 12.1 (40). С. 791-794.

10. Про затвердження Положення про організацію внутрішнього контролю в банках України : Постанова Національного банку України від 29.12.2014 № 867 // База даних «Законодавство України» / Верховна Рада України. URL: http://zakon3. rada.gov.ua/laws/show/v0867500-14

11. Сарахман О., Козьол В. Функціонування комплаєнсконтролю у вітчизняній банківській справі. Бухгалтерський облік, аналіз і аудит. 2015. Вип. 2 (112). С. 87-90.

12. Compliance and the compliance function in banks. URL: https://www.bis.org/publ/bcbs113.pdf

13. OECD Report toG20 Finance Ministers and Central Bank Governors. URL: https://www.oecd.org/daf/ca/Corporate-Governance-Principles-ENG.pdf

\section{REFERENCES}

Astrakhantseva, I. A., Dubov, D. A., and Kutuzova, A. S. "Komplaens-kontrol v kommercheskom banke" [Compliance control in a commercial bank]. http://www.astrakhantseva.ru/pub/fin_2014_6. pdf

Bereslavska, O. I. "Perspektyvy implementatsii rekomendatsii Bazelskoho komitetu v praktychnu diialnist bankiv Ukrainy" [Prospects for the implementation of the recommendations of the Basel Committee in the practical activities of the Ukrainian banks]. Naukovi zapysky Khersonskoho natsionalnoho universytetu. Seriia «Ekonomika», no. 23 (2013): 262-266.

"Compliance and the compliance function in banks". https:// www.bis.org/publ/bcbs113.pdf

Honcharova, K. H. "Systema komplaiens yak element ekonomichnoi bezpeky banku" [Compliance system as an element of the bank's economic security]. Visnyk Cherkaskoho universytetu. Seriia «Ekonomichni nauky», no. 33 (366) (2015): 27-36.

Kalinichenko, L. L. "Teoretychni aspekty funktsionuvannia komplaiensu u vitchyznianykh bankakh" [Theoretical aspects of the functioning of compliance in domestic banks]. Naukovyi visnyk Khersonskoho derzhavnoho universytetu. Seriia «Ekonomichni nauky», vol. 4, no. 6 (2014): 242-245.

Kliusko, L. A. "Finansovyi monitorynh ta komplaiens-kontrol v bankakh" [Financial monitoring and compliance control in banks]. Fynansy, uchet, banky, no. 1 (20) (2014): 153-160.

Koliada, I. V. "Poniattia ta sutnist komplaiens-kontroliu u vitchyznianii ekonomichnii nautsi ta suspilnomu dyskursi" "Concept and essence of compliance control in the national economic science and public discourse]. Molodyi vchenyi, no. 12 (2016): 1-40.

Kovalchuk, O. "Poniattia systemy komplaiens-kontrol ta osoblyvosti upravlinnia ryzykom komplaiens u bankakh Ukrainy" [Concept of Compliance-Control System and Peculiarities of Risk Compliance in Ukrainian Banks]. Molod i rynok, no. 7 (2010): 153-157.

[Legal Act of Ukraine] (2014). http://zakon3.rada.gov.ua/ laws/show/v0867500-14

"OECD Report toG20 Finance Ministers and Central Bank Governors". https://www.oecd.org/daf/ca/Corporate-GovernancePrinciples-ENG.pdf

Sarakhman, O., and Kozyol, V. "Funktsionuvannia komplaiens-kontroliu u vitchyznianii bankivskii spravi" "Functioning of Compliance Control in the domestic banking business]. Bukhhalterskyi oblik, analiz i audyt, no. 2 (112) (2015): 87-90.

Vnukova, N. M. “Upravlinnia ryzykamy finansovykh ustanov u sferi finansovoho monitorynhu" [Risk management of financial institutions in the field of financial monitoring]. Naukovi zapysky Natsionalnoho universytetu "Ostrozka akademiia». Seriia «Ekonomika», no. 8 (36) (2018): 64-68.

Zharii, Ya., and Kufaieva, V. "Komplaiens-model protsesu zabezpechennia finansovoi bezpeky komertsiinoho banku" [Compensation model of the financial security of a commercial bank]. Problemy i perspektyvy ekonomiky ta upravlinnia, no. 2 (6) (2016): 312-319. 